\title{
Bethencourt (Francisco), The Inquisition. A Global
} History, 1478-1834

translated by Jean Birrell, Cambridge and New York, Cambridge University Press, 2009, Xii+491pp., including 40 b\&w Plates, ISBN 978-0-521-74823-0 (pb)

\section{Christopher F. Black}

\section{OpenEdition}

Electronic version

URL: https://journals.openedition.org/chs/1227

DOI: $10.4000 /$ chs. 1227

ISSN: 1663-4837

Publisher

Librairie Droz

\section{Printed version}

Date of publication: 1 December 2010

Number of pages: 156-159

ISBN: 978-2-600-01470-0

ISSN: $1422-0857$

\section{Electronic reference}

Christopher F. Black, "Bethencourt (Francisco), The Inquisition. A Global History, 1478-1834", Crime Histoire \& Sociétés / Crime, History \& Societies [Online], Vol. 14, n² | 2010, Online since 02 December 2010, connection on 23 March 2022. URL: http://journals.openedition.org/chs/1227 ; DOI: https:// doi.org/10.4000/chs. 1227 
Bethencourt (Francisco), The Inquisition. A Global History, 1478-1834, translated by Jean Birrell, Cambridge and New York, Cambridge University Press, 2009, Xii+491pp., including 40 b\&w Plates, ISBN 978-0-521-74823-0 (pb)

This is an expanded translation of Bethencourt's L'Inquisition à l'époque moderne. Espagne, Italie, Portugal, XV $V^{e}-X I X^{e}$ siècles (Fayard, Paris, 1995). For this edition the author had provided an enlarged introduction, with a bibliographical survey commenting on developments in the study of the different inquisitions and rival approaches, and he has incorporated recent studies in the notes and bibliography. A few paragraphs thereafter have been added or altered, mainly concerning Italy in taking advantage of work by Andrea Del Col and Agostino Borromeo, (see especially pp. 50, 85-91, 174, 236, 443-446). Three Maps have been added locating the established local tribunals. Professor Bethencourt has long been a major contributor (largely in Portuguese), to the study of the inquisition in Portugal and its colonies, now reflected in his holding the Charles Boxer Chair at King's College, London. His knowledge of the Spanish inquisition is also considerable, and he has drawn on

19 La dynamique de l'Occident, Paris, Agora-Pocket, 1975, pp. 316-317. 
archival sources of some Italian tribunals (notably Bologna, Modena, Udine and Venice), to illuminate his comparative study. However in the long gap between the original French edition and this translation he seems not to have taken direct advantage of the 1998 opening to scholars more widely of the central Holy Office in Rome, (Archivio della Congregazione per la Dottrina della Fede). The reviewer's expertise is the inverse to Bethencourt's; given his recent publication of The Italian Inquisition (Yale University Press), he is inclined to concentrate his criticisms on the Italian scene (which included Spanish inquisition tribunals in Sicily and Sardinia). The attempt to provide a comparative analysis of the early modern inquisitions is welcome, the outcome impressive in the range of scholarship shown, throwing much new light on the institutional structures and on the different interfaces with the wider societies. Yet, the densely packed book is not an easy read, and it is a shame that in being allowed to make some revisions and expansions, and producing the book fifteen years after the original, the author did not heed comments on the original edition, as by Henry Kamen, and made it a little more accessible to those being less experienced to inquisition history.

We have here an impressive comparative study of the inquisitorial institutions from origins to closures, how they were founded and developed, their operational procedures as institutions, the links between central organisation and the local tribunals. Bethencourt also considers the problems in dealing with kings, princes and republics like Venice, and with bishops. He does not here make trials and their victims a major focus of attention, though as a trained lawyer he has previously analysed trial records (pp. 32-33). He does attempt to calculate the numbers of accused, and the typology of victims, with useful tables, (pp. 334-348), and reflects on evidence of social backgrounds of the accused. But this book does not introduce the reader to due processes of investigation and trial, subtleties of judgement and punishment, inter-relationships between accusers, accused and inquisitors, with possibilities of plea-bargaining (as I have shown for the Roman Inquisition). Bethencourt rightly stresses that the main aim of most inquisitorial labour was to secure confessions (pp. 67-69). To his saying that asking denouncers and witnesses whether they had enmity towards the accused was just 'for form's sake', I would suggest that Italian inquisitors at least did have this in mind when deciding whether to pursue the accusations to full trial. The translation here of procès (Italian processo) as 'trial' can be misleading, since the English implies a full process leading to a verdict, when many 'cases' in the statistics (as Bethencourt does admit), especially in Italy are of denunciations (and self-denunciations), followed by varying degrees of investigation - or none, but with many not leading to formal charges, abjuration or punishment. The reader receives no real indication of what famous investigations, tangentially mentioned, of men like archbishop Carranza, Antonio Perez, Giordano Bruno or Galileo involved; and they can throw much light on different institutional approaches, and power struggles within the Churches. They would also provide a human interest that is rather lacking here.

Bethencourt's 'new model of research' is based on four approaches: rites and etiquette, organisational forms, strategies of action, and systems of representation (p. 29). The first approach runs through much of the book, with the author writing very fully of the rituals involved in appointing inquisitorial officials, in their introduction to jobs and social roles. He sees rituals, orders of precedence and comparative status, as a key to the infiltration of Iberian inquisitions into state and society, and winning of public acceptance. (Such issues are less important in mainland Italy, 
though strong in Spanish Sicily). Much is made of the number and roles of 'familiars', privileged assistants, supporters and hangers-on from wider society, who might defend inquisitors, add to their prestige and display in formal parades, and secure social-political acceptance. Battles over privileges such as tax exemptions and right to carry guns could also create discord with local secular authorities. In the Italian scene Bethencourt seems to use 'familiars' and crocesignati (named after a cross-badge worn on robes) as interchangeable; the latter term I think should be reserved for those formally enrolled in confraternities of that name (or something similar), as in Bologna and Modena, when not all privileged familiars were so associated. In dealing with organisational forms, the discussion could have been fuller and clearer about the situation in the Kingdom of Naples, where the papacy as feudal superior would not accept the Spanish rulers' desire to have branches of the Spanish Inquisition, and they in turn as de facto rulers would not allow the Roman Inquisition to operate tribunals openly; though Rome did exercise power more surreptitiously through commissioners and the episcopacy, as recent work has well illustrated.

For this reviewer the highlights of the book include the long chapter 7 on the auto-da-fé, with massive fascinating details on their complex organisation in the Iberian systems, the elaborate structures, the public ceremonies, the importance of etiquette for the observing participants, the treatment of those to die, and those not. Bethencourt is not really concerned with the fewer and less spectacular autos under the Roman Inquisition, but rightly indicates that these concerned individuals or a small group, while the Iberian were regular mass celebrations. Chapter 9 on 'Representations' stimulatingly discusses visual and verbal publicity for the actions of the inquisitions, (again primarily Iberian), whether favourably propagandist, or antagonistic contributions to the Black Legend. The physician Charles Dellon's 1687 memoirs of his experiences of the Goa inquisition (seen as the harshest colonial tribunal), and illustrations accompanying publication are seen as very damaging to the reputations of inquisitions. Chapters 5 and 6 on 'The Edicts' and 'The visits', while very dense for a general reader, are valuable for specialists, and do illustrate the extent to which inquisitors from the centre, and locally, sought to control society, and its moral conduct beyond strict theological heresies. The effectiveness of publishing edicts - general or specific - is hard to gauge. Inquisitorial visitations checked on the conduct of inquisitors and their familiars in Iberia, but were not used in Italy. Spanish inquisitors were noted for visits to ports, netting heretical foreigners. 'Visits' allows some consideration of book censorship, though room was presumably lacking to reflect on recent work on the Roman Congregation of the Index and its newly accessible archive. Bethencourt follows those scholars who see Spanish censorship as highly detrimental to the sciences.

Among the differences between the inquisitions Bethencourt emphasises that Iberian inquisitors tended to be lawyers, while the Roman ones were theologians (especially Dominicans); Iberian ones could be more fully integrated at the top level into court or state politics; there nepotism could be important, and especially in Portugal contact with the inquisition facilitated social promotion. 'Purity of Blood' concepts came later in Portugal, and seem less important than in Spain; and they are not an Italian consideration, where problems of New Christians were comparatively minor (and treated with leniency in places like Venice). Bethencourt suggests that when the Judaism and Morisco problems diminished the pursuit of other offences like superstition, clerical solicitation in confessionals, or lay sexual deviancy was 
needed to justify the continuing activity of the institutions; "new suspects had to be found' (p. 350); there was 'a quest for functionality' (p. 352). This implies a considerable degree of pro-activeness; but my investigations of the Italian scene indicate much stemmed from neighbourly fears and denunciations. We agree that those suspects of magical and superstitious practices were likely to be more leniently treated by inquisition tribunals than by other clerical or lay courts.

Despite the above quibbles and frustrations over certain omissions I applaud this valiant attempt at a global analysis of the inquisitions as institutions. His comparative approach brings out their considerable impact socially and politically in Spain, Portugal and their colonies; while the public profile of the Roman Inquisition, and the 'medieval' or 'episcopal' in the Kingdom of Naples was less.

Christopher F. Black University of Glasgow c.black@history.arts.gla.ac.uk 